\title{
BCORL1 wt Allele
}

National Cancer Institute

\section{Source}

National Cancer Institute. BCORL1 wt Allele. NCI Thesaurus. Code C131269.

Human BCORL1 wild-type allele is located in the vicinity of Xq26.1 and is approximately 78 $\mathrm{kb}$ in length. This allele, which encodes BCL- 6 corepressor-like protein 1 , is involved in the inhibition of transcription. Mutation of the gene may be associated with acute myeloid leukemia and head and neck squamous cell carcinoma 